\title{
KRAS NP_004976.2:p.G12F
}

National Cancer Institute

\section{Source}

National Cancer Institute. KRAS NP 004976.2:p.G12F. NCI Thesaurus. Code C98375.

A change in the amino acid residue at position 12 in the GT Pase KRas protein where glycine has been replaced by phenylalanine. 